\title{
Subsurface Lateral Flow in Texture-Contrast (Duplex) Soils and Catchments with Shallow Bedrock
}

\author{
Marcus A. Hardie, ${ }^{1,2,3}$ Richard B. Doyle, ${ }^{1,2}$ William E. Cotching, ${ }^{3,4}$ and Shaun Lisson ${ }^{5}$ \\ ${ }^{1}$ Tasmanian Institute of Agricultural, University of Tasmania, PB 98, Hobart, TAS 7001, Australia \\ ${ }^{2}$ School of Agricultural Science, University of Tasmania, PB 54 Hobart, TAS 7001, Australia \\ ${ }^{3}$ Department of Primary Industries, Parks, Water and Environment (DPIPWE), GPO Box 44, Hobart, TAS 7001, Australia \\ ${ }^{4}$ Tasmanian Institute of Agricultural Research, University of Tasmania, P.O. Box 3523 Burnie, TAS 7320, Australia \\ ${ }^{5}$ CSIRO Sustainable Ecosystems, University of Tasmania, PB 98, Hobart, TAS 7001, Australia
}

Correspondence should be addressed to Marcus A. Hardie, marcus.hardie@utas.edu.au

Received 7 June 2011; Revised 5 October 2011; Accepted 24 October 2011

Academic Editor: Keith Smettem

Copyright (C) 2012 Marcus A. Hardie et al. This is an open access article distributed under the Creative Commons Attribution License, which permits unrestricted use, distribution, and reproduction in any medium, provided the original work is properly cited.

Development-perched watertables and subsurface lateral flows in texture-contrast soils (duplex) are commonly believed to occur as a consequence of the hydraulic discontinuity between the A and B soil horizons. However, in catchments containing shallow bedrock, subsurface lateral flows result from a combination of preferential flow from the soil surface to the soil-bedrock interface, undulations in the bedrock topography, lateral flow through macropore networks at the soil-bedrock interface, and the influence of antecedent soil moisture on macropore connectivity. Review of literature indicates that some of these processes may also be involved in the development of subsurface lateral flow in texture contrast soils. However, the extent to which these mechanisms can be applied to texture contrast soils requires further field studies. Improved process understanding is required for modelling subsurface lateral flows in order to improve the management of waterlogging, drainage, salinity, and offsite agrochemicals movement.

\section{Introduction}

Texture-contrast soils (duplex) cover approximately $20 \%$ of the Australian land mass [1] or 2.33 million $\mathrm{km}^{2}$ [2]. According to Chittleborough et al. [3] texture-contrast soils occur on around $80 \%$ of agricultural regions in southern Australia and around $60 \%$ of the agricultural regions of south-western Western Australia [4]. The term "texture-contrast soil" has not been explicitly defined in a formal soil classification system. The term "texture-contrast" was first used in the Great Soil Group [5] and Handbook of Australian Soils [6] in reference to the solonetz, solodized solenetz, and the soloths, which all have a marked texture-contrast between the upper and lower horizons. Northcote [7] described the texturecontrast soils as "duplex" in which the subsoil (B horizon) texture is at least one and a half texture groups finer than the surface soil (A Horizon), and horizon boundaries are clear to sharp. The Australian Soil Classification [8] identified three soil orders: Sodosols, Kurosols, and Chromosols, which have a clear or abrupt textural B horizons. Although the term "duplex" has only been used in Australia, soils with contrasting texture between soil horizons are found in other parts of the world [9]. In "Soil Taxonomy" [10], soils showing characteristics most like those of the duplex soils are classified with the formative element "pale" meaning to show excessive development. This includes 15 Great Groups in 3 orders: the Mollisols, Ultisols, and Alfisols. In the FAO-UNESCO World Soil Map (FAO-UNESCO 1987), duplex soils are accommodated in a range of classes, principally the Solonetz and Luvisol units [9].

Texture-contrast soils are associated with a range of management problems including waterlogging, poor crop establishment, crusting, poor root penetration, desiccation, wind erosion, water erosion, tunnel erosion, salinity, and poor nutritional status $[4,11-16]$. Texture-contrast soils are naturally very hard setting [17] and suffer low infiltration rates and poor water holding capacity [18], which is accentuated where excessive cultivation has occurred [13]. The presence 
of massive, poorly drained subsoils results in regular seasonal waterlogging, which results in poor aeration for roots, nitrogen deficiency, and increased manganese levels where $\mathrm{pH}$ is low [13]. Reduced crop yields in texture-contrast soils result from soil erosion, crusting, limited rooting capacity, poor aeration resulting from the slow movement of soil water through the upper $\mathrm{B}$ horizon, and confining of roots to shrinkage cracks and ped faces in the subsoil [19-25]. In landscapes with sufficient slope, perched water-tables may be exacerbated by lateral movement of water on the upper surface of the B horizon leading to waterlogging and salinity in lower parts of the landscape $[13,22,26]$.

Given the extensive use of texture-contrast soils for agricultural production in Australia, greater understanding of the processes by which water and solutes are stored and mobilized in texture-contrast soils is important for both agricultural production and environmental protection. Improved process understanding of the mechanisms by which perched water-tables and subsurface lateral develop in texture-contrast soils is required for further model development in order to reduce the incidence of waterlogging, improve irrigation efficiency, and minimise the offsite mobilization of nutrients and agrochemicals to waterways.

This paper reviews and compares the Australian literature on the development of perched water-tables and subsurface lateral flows in texture-contrast soils, with international studies of subsurface lateral flows in steep, forested catchments with shallow bedrock. Differences in process understanding and soil water modelling between the two landscapes are articulated, the transferability of process understanding to texture-contrast soils is discussed, and recommendations for future field research and model development are provided.

\section{Subsurface Lateral Flow in Australian Texture-Contrast Soils}

Subsurface lateral flow refers to soil water processes in which infiltrating water accumulates and moves laterally downslope along the upper surface of a less permeable layer in the soil.

Subsurface lateral flow is known by a range of terms including throughflow, subsurface storm flow, subsurface runoff, and interflow, for example, Gregory et al. [27], Lehman and Ahuja [28], and Ticehurst [29]. Subsurface lateral flow in hillslopes may occur as saturated, unsaturated, or macropore flow [30-32]. Subsurface lateral flow has been reported from a range of soil types, including uniform soils [33], layered soils $[29,31]$, sands $[33,34]$, and may occur simultaneously at multiple depths $[29,35]$.

Review of the Australian literature indicates that subsurface lateral flows are a relatively minor component $(<10 \%)$ of the hydrological budget under rainfed conditions [29]. Little data is available to make similar assessment in irrigated landscapes despite the widespread occurrence of irrigated agriculture on texture-contrast soil. Gregory et al. [27] have shown that the ratio of subsurface lateral flow to rainfall varies between catchments and also between years within the same catchment. Studies by Cox and Ashley, [36], Cox et al. [37], Cox and Pitman [38], and Stevens et al. [39] have demonstrated that nutrient and cation transport via subsurface lateral flow varies between hillslope position and rainfall events. Stevens et al. [39] found that environmentally significant amounts of both dissolved and particulate phosphorus, nitrate and dissolved organic carbon moved as subsurface lateral flow via macropores at the A/B boundary in texturecontrast soils in the Adelaide Hills. In the Keynes Catchment, South Australia, $89 \%$ of total flow occurred as subsurface lateral flow. Nitrate losses were found to be up to 21 times higher in subsurface flow than in overland flow, while losses of $\mathrm{DOC}, \mathrm{Na}, \mathrm{Cl}, \mathrm{Al}, \mathrm{Fe}, \mathrm{K}$, and $\mathrm{Mg}$ were also found to be higher in subsurface lateral flow than overland flow $[36,38]$. Cox et al. [37] explain that solute variability in subsurface lateral flow results from differences in the relative contribution to flow from macropores and the soil matrix.

In texture-contrast soils, development of perched watertables and subsurface lateral flow is generally believed to result from rainfall and infiltration through the A horizon at rates which exceed the hydraulic conductivity of the clay subsoil [24]. The importance of macropores and soil water status to the development of subsurface lateral flow and solute movement is poorly understood and has generally been ignored in most field and modelling studies. A number of studies, however, indicate the potential influence of macropore flow on the prevention of perched water-tables and subsurface lateral flows in texture-contrast soils. Smettem et al. [40] found that soil macroporosity and by-pass flow were responsible for preventing subsurface lateral flow at the A/B horizon boundary. Bypass flow through soil macropores in the B horizon resulted in field saturated hydraulic conductivities that were considerably higher than would be predicted from textural analysis. Consequently, the distinct textural boundary within the profile did not act as a throttle to vertical infiltration, resulting instead in subsurface lateral flow lower in the profile, along the soil/rock interface rather than the boundary of the A and B horizons. Brouwer and Fitzpatrick [41] also reported that macroporosity resulting from root holes which pre-dated land clearance, provided sufficient hydraulic connectivity to prevent the development of subsurface lateral flow on a series of texture-contrast soils in the Dundas Tablelands, Western Victoria.

\section{Subsurface Lateral Flow in Steep Catchments with Shallow Bedrock}

The majority of international studies on subsurface lateral flow or throughflow have been conducted in steep, usually forested catchments, with shallow bedrock or impeding layers within approximately two meters of the soil surface. In a series of studies at the Maimai catchment, New Zealand, McDonnell [44] and McDonnell et al. [48, 49] demonstrated that subsurface flow occurred as a two-component system, consisting of both rapid macropore flow and slow matrix flow. Macropore flow via vertical cracks resulted in rapid saturation of the profile base ahead of a slower moving wetting front in the soil matrix. Development of perched water-tables was short lived due to the presence of interconnected pipes at the soil-bedrock interface. At the H.J Andrews Experimental Forest in Oregon, van Verseveld et al. [50] demonstrated that 


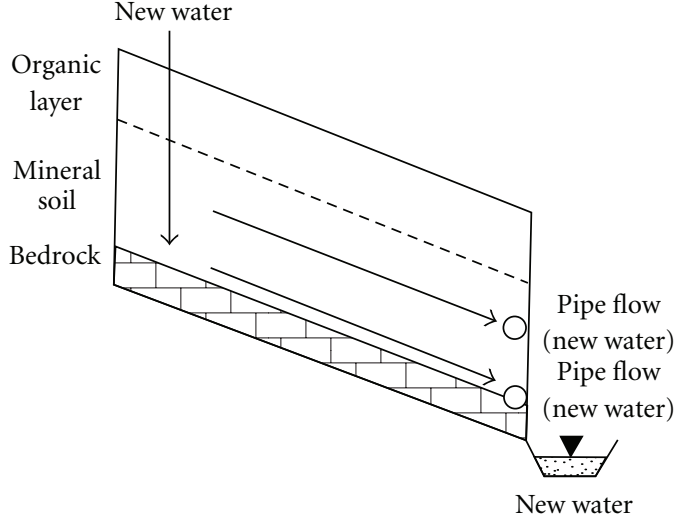

(a) Mosely [42]

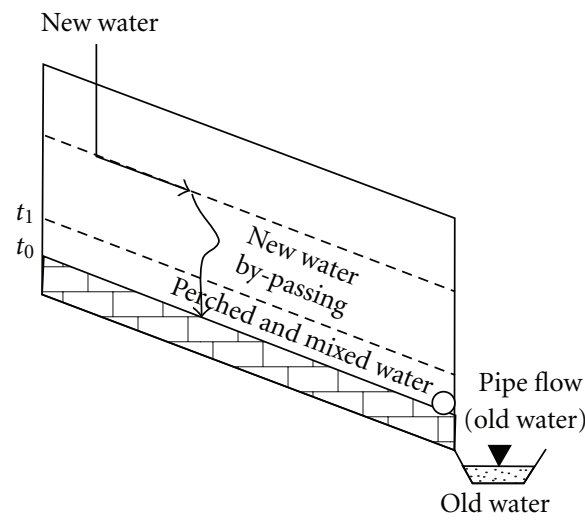

(c) McDonnell [44]

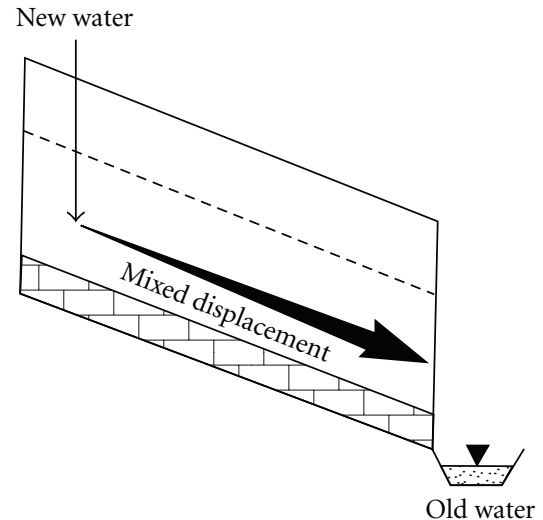

(b) Sklash et al. [43]

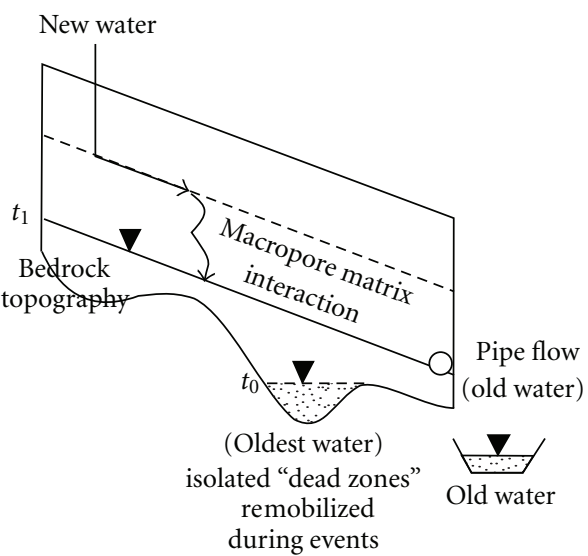

(d) Brammer and McDonnell [45]

FIGURE 1: Changing conceptual understanding of subsurface flow in the Maimai catchment, New Zealand McGlynn et al. [46].

subsurface lateral flow also resulted from vertical transport of rainfall from the soil surface to the soil-bedrock interface by preferential flow in which saturation of the entire soil profile was not required to develop saturation at the soil-bedrock interface. In the Maimai catchment, McDonnell et al. [45] revealed significant bedrock surface control on subsurface flow timing and tracer breakthrough. Brammer [51] and McDonnell et al. [45] also demonstrated that small depressions and microtopographic relief in the bedrock surface exerted a large control on water mobility and mixing. Whereas previous studies had tended to treat the soil-bedrock interface as a relatively smooth, linear feature, parallel with the soil surface, Brammer [51] and McDonnell et al. [45] showed that the bedrock surface appeared to determine the pathway of mobile subsurface water flow and tracer breakthrough during events at the hillslope scale (Figure 1). The importance of the bedrock properties on subsurface lateral flow development, location, and velocity was further demonstrated by Graham et al. [52] who concluded that downslope flow in the Maimai catchment was concentrated at the soil bedrock interface in which flow path location was controlled by small variations in topography and permeability of the bedrock topography. They found that despite considerable vertical percolation through the bedrock, subsurface lateral flow along the bedrock surface occurred at flow velocities several orders of magnitude greater than that predicted by Darcy's law.

Research in Japan by Sidle et al. $[53,54]$ and Tsuboyama et al. [55] sought to resolve the apparent contradiction between the presence of a connected systems of macropores proposed by McDonnell [44] and dye tracer studies such as Sidle et al. [53], which demonstrated that flow through macropores was short and discontinuous. Tsuboyama et al. [55] demonstrated that the scale at which macropores became effective depended on their connectivity, which increased at higher antecedent moisture content. Sidle et al. [53] also demonstrated that although individual macropore segments were generally less than $0.5 \mathrm{~m}$ in length, they had a tendency to self-organise into larger preferential flow systems which expanded upslope as antecedent soil moisture increased. They proposed that such dynamic preferential flow systems are linked by a series of "nodes" of connectivity that can be conditioned by different levels of antecedent moisture.

Studies at the Panola Mountain Research Watershed, Georgia, have demonstrated the importance of bedrock structures on the development of subsurface lateral flows. Tromp-Van Meerveld and McDonnell $[47,56]$ described the threshold-dependant occurrence of subsurface lateral flow as a "fill and spill" process, in which water ponding at the soil 
bedrock interface overfilled bedrock depressions, causing water to "spill" downslope over the bedrock surface. During storm events, water ponding at the soil bedrock interface overfilled the top of the bedrock depression, causing water to "spill" downslope over the bedrock ridge towards the trench face. Subsurface flow was restricted to the bedrock lows as a series of narrow ribbons of "channelised" saturated flow. As antecedent soil moisture increased during rainstorm events, the saturated depressions become more connected resulting in increased subsurface flow at the trench face (Figure 2). Later studies by Tromp-van Meerveld et al. [57] and Wang [58] demonstrated the underlying bedrock was not impermeable and that leakage from subsurface lateral flow and saturated depressions in the bedrock to the aquifer were an important component of the water balance. Through the use of ground-penetrating radar and electromagnetic induction, Yoder et al. [59] and Gish et al. [60] also demonstrated that the topography of the impeding layer resulted in narrow ribbons of "channelized-" saturated flow in a loess soil and a fluvial deposit.

\section{Comparison between Texture-Contrast Soils and Catchments with Shallow Bedrock}

In contrast to the extensive studies of subsurface lateral flow in the Panola and Maimai catchments, process understanding of the mechanisms responsible for development of seasonal perched water-tables and subsurface lateral flows in texture-contrast soils is lacking.

In order to transfer knowledge and understanding of hydrological processes from catchments with shallow bedrock to catchments containing texture-contrast soils, the similarities and differences between these two landscapes need to be clearly articulated. Of the catchments included in this paper, all are relatively steep, (average $34^{\circ}$ at Maimai, and $13^{\circ}$ at Panola), have high rainfall (2600 $\mathrm{mm}$ at Maimai to $1240 \mathrm{~mm}$ at Panola), and are predominantly covered by forest $[46,47$, $53,56,57,61]$. Depth to bedrock varies between and within catchments, at the Maimai catchment the average depth of the soil profile is $77 \mathrm{~cm}$ [46], while at the Panola catchment soil depth varied from 0 to 1.8 meters on the hillslopes to 5-10 meters in the valley bottoms [62]. At the Maimai catchment, infiltration rates were up to $146 \mathrm{~m} /$ day, while saturated hydraulic conductivity ranged from 0.24 to $7.2 \mathrm{~m} /$ day. Bedrock permeability was estimated by McGlynn et al. [46] to be $0.1 \mathrm{~m} / \mathrm{yr}$, and by Graham et al. [52] to be $0.02-0.07 \mathrm{~m} /$ day at the Maimai catchment and $0.14 \mathrm{~m} /$ day at the Panola catchment [52].

In Australia, catchments containing texture-contrast soils tend to occur in low-to-moderate rainfall zones $(600 \mathrm{~mm}-$ $1200 \mathrm{~mm}$ ), on plains or gently undulating to rolling landscapes [63]. They are frequently used for agriculture including cropping on lower slopes, and dryland grazing, forestry, or perennial horticulture on mid to upper slopes $[39,64]$. Subsoil permeability generally ranges from moderate to very slow ( $0.5 \mathrm{~m} /$ day to $<0.0005 \mathrm{~m} /$ day) [63]. Measured values of subsoil saturated hydraulic conductivity may, however, vary by up to two orders of magnitude over a 10-meter distance [22]. Reported values of subsoil hydraulic conductivity

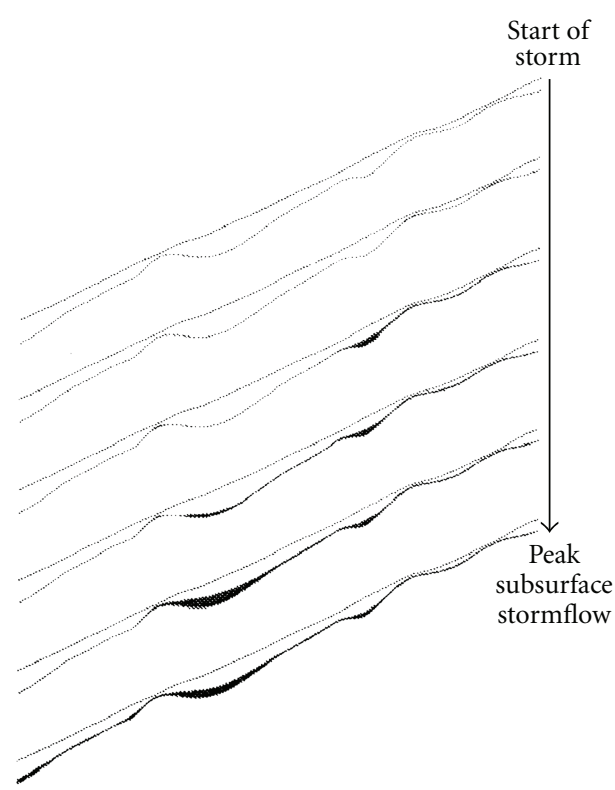

FIgure 2: Schematic representation of the fill and spill process. The shaded areas represent the locations of subsurface saturation. The vertical exaggeration is 2 times [47].

include $0.0001-0.20 \mathrm{~m} /$ day [4], $0.002-1.20 \mathrm{~m} /$ day [22], $0.012 \mathrm{~m} / \mathrm{y}$, and $0.0003 \mathrm{~m} / \mathrm{y}$ [39]. Hardie et al. [65] reported that near saturated hydraulic conductivity $(\psi-0.13 \mathrm{kPa})$ in the subsoil of a texture-contrast soil varied significantly depending on antecedent soil moisture content. Silberstein et al. [66] also postulated that seasonal swelling of a duplex soil resulted in several orders of magnitude reduction in hydraulic conductivity. Little data is available to indicate depth to bedrock in texture-contrast soils; however, Tennant et al. [4] argues that depth to the $\mathrm{B}$ horizon, generally $<0.3 \mathrm{~m}$, is the more important attribute for predicting development of subsurface lateral flow in texture-contrast soils.

Whilst subsurface lateral flows occur in both texturecontrast soils and catchments with shallow bedrock, important differences exist between the two landscapes that are thought to influence the processes responsible for the development of lateral flow. In comparison to texture-contrast soils, subsurface lateral flow in catchments with shallow bedrock is facilitated by higher slopes, greater rainfall, and generally greater impediment to vertical flow through the bedrock. In texture-contrast soils, the depth to the impeding layer (upper B horizon) is rarely deeper than 0.3 meters, compared with up to many meters in the forested catchments. Consequently, it may be expected that less rainfall is required to saturate the soil profile and induce saturation at the impeding layer in the texture-contrast soils, than in catchments with shallow bedrock. However, McDonnell [44] and van Verseveld et al. [50] demonstrated, in the Maimai and Panola catchments, that macropore flow enabled rainfall to be routed from the soil surface to the soil- bedrock interface without having to saturate the soil profile. In contrast to the mostly forested catchments with shallow bedrock, agricultural practices, such as tillage, compaction, and loss of 
organic carbon are thought to curtail macropore flow in the topsoil of most texture-contrast soils [11]. Consequently, in texture-contrast soils, saturation at the A/B horizon boundary is more likely to require sufficient rainfall to saturate the entire A horizon.

In contrast to catchments with shallow bedrock, preferential flow in the subsoil of some texture-contrast soils is thought to prevent rather than facilitate the occurrence of perched water-tables and subsurface lateral flow. Smettem et al. [40], Brouwer and Fitzpatrick [41], Silberstein et al. [66] and Hardie et al. [67] have demonstrated that macropores and shrinkage cracks in the subsoil of at least some texturecontrast soils prevent rather than enhance the development of perched water-tables by enabling infiltration to penetrate into the subsoil rather than to accumulate on the upper surface of the B horizon.

Development of saturation and subsurface lateral flow above an impeding layer requires the rainfall intensity to exceed the hydraulic conductivity of the impeding layer. In the past, most hillslope studies have assumed the underlying bedrock to be relatively impermeable [57]. While studies such as Tromp-van Meerveld et al. [68] and Tromp-van Meerveld and Weiler [57] have been increasingly challenging this view, the subsoil hydraulic conductivity of bedrock in most catchments with shallow bedrock tend to be substantially lower than the hydraulic conductivity of most texturecontrast soils. Furthermore, unlike bedrock, the upper surface of at least some texture-contrast soils are known to vary seasonally with antecedent soil moisture $[65,66]$. While antecedent soil moisture has been shown to increase subsurface lateral flow in both texture-contrast soils and catchments with shallow bedrock, the processes involved are thought to differ. In catchments with shallow bedrock, higher soil moisture increases connectivity between depressions in the bedrock surface $[47,56]$ and macropore segments [53]. Whereas in texture-contrast soils with vertic subsoils, higher soil moisture status is thought to cause clay subsoils to swell resulting in the closure of shrinkage cracks and reduction in hydraulic conductivity of the B horizon [66].

\section{Progress towards Improved Modeling of Subsurface Lateral Flow}

Many studies have used simulation models to better predict or understand the occurrence of subsurface flows in both texture-contrast soils and catchments with shallow bedrock. Interest in the use of modelling tools results from difficulties associated with measuring subsurface flows, and the ability of modeling tools to extend results from small plot experiments to larger scales. Early numerical models of subsurface lateral flow were based on simple conceptual models such as that proposed by Whipkey and Kirkby [69]. In this model, rainfall infiltrates the surface soil and ponds above an impeding or impermeable layer, as rainfall continues, the saturated layer; becomes thicker and develops upslope as a saturated wedge resulting in subsurface lateral flow at a trench face (Figure 3).

Simple conceptual understanding of subsurface lateral flow has been retained in most numerical models of water movement in texture-contrast soils. Typically, subsurface lateral flow is represented as a single flow path through the soil matrix, impeded by a layer that runs parallel to the soil surface and characterised by a single value for hydraulic conductivity, for example, Cook and Rassam [70], Stolte et al. [71], Ticehurst et al. [72], Smith and Hebbert [73]. This simplicity results from both limited understanding of the processes responsible for generation of subsurface lateral flow in texture-contrast soils, particularly the role of preferential flow, and lack of field data required to adequately represent the spatial and temporal variations of the soil hydraulic properties. While some comparative studies indicate that increased model sophistication does not necessarily result in better simulation of subsurface lateral flows [74], as a general principle models should be no simpler than necessary to represent the dominant hydrological processes [75].

Lin et al. [76] report that many catchment and hillslope models do a poor job of accurately predicting the relative contributions to stream flow from subsurface lateral flow, baseflow, and surface runoff. Poor performance results from a combination of complex local flow pathways and difficulty with the measurement of soil-water properties at appropriate scales. Weiler and McDonnell [77] also note that conceptualization and parameterization of the effects of lateral macropore flow on hillslope hydrology currently represents the greatest challenge in modeling macropore processes at the catchment scale. They explain, the difficulty does not result from inadequate understanding of flow processes at the Darcy scale, but rather from the inability to adequately represent the spatial topology and temporal variation of macropore networks that determine the rate and extent of preferential flows through field soils at larger scales.

Early attempts to simulate the effects of preferential flow at the hillslope scale used pipe flow models based on Manning's equation to simulate flow through macropore networks at the soil-bedrock interface [77-79]. Difficulty in the use of hydraulic pipe flow models resulted from differences in flow behavior between pipes and macropores including, full flow and partial flow, pipe geometry and roughness, pipe occlusion, pipe branching, and increasing development of macropore networks with increasing antecedent moisture $[78,80]$. In the recent years, two-dimensional multiple porosity models such as SWAP [81] and Hydrus-2D [82] have been developed to simulate nonequilibrium flow in macroporous soils [83]. Review of multiple porosity models is presented by Köhne et al. [84], Simunek et al. [83], and Simunek and van Genuchten $[82,85]$. Briefly these models assume that the porous media consists of two interacting regions, one associated with the interaggregate, macropore, or fracture system, and one comprising micropores inside soil aggregates or the soil matrix. The actual size, form, and number of macropores are not explicitly. Instead the macropore characteristics are captured by the unsaturated soil hydraulic properties near saturation as described by van Genuchten [86] or Durner [87] equations, and mass transfer parameters that enable exchange between the micropore and macropore domain [88]. These models assume that water and solutes can move instantaneously to specified depths while by-passing the soil matrix once the infiltration capacity of the soil matrix 


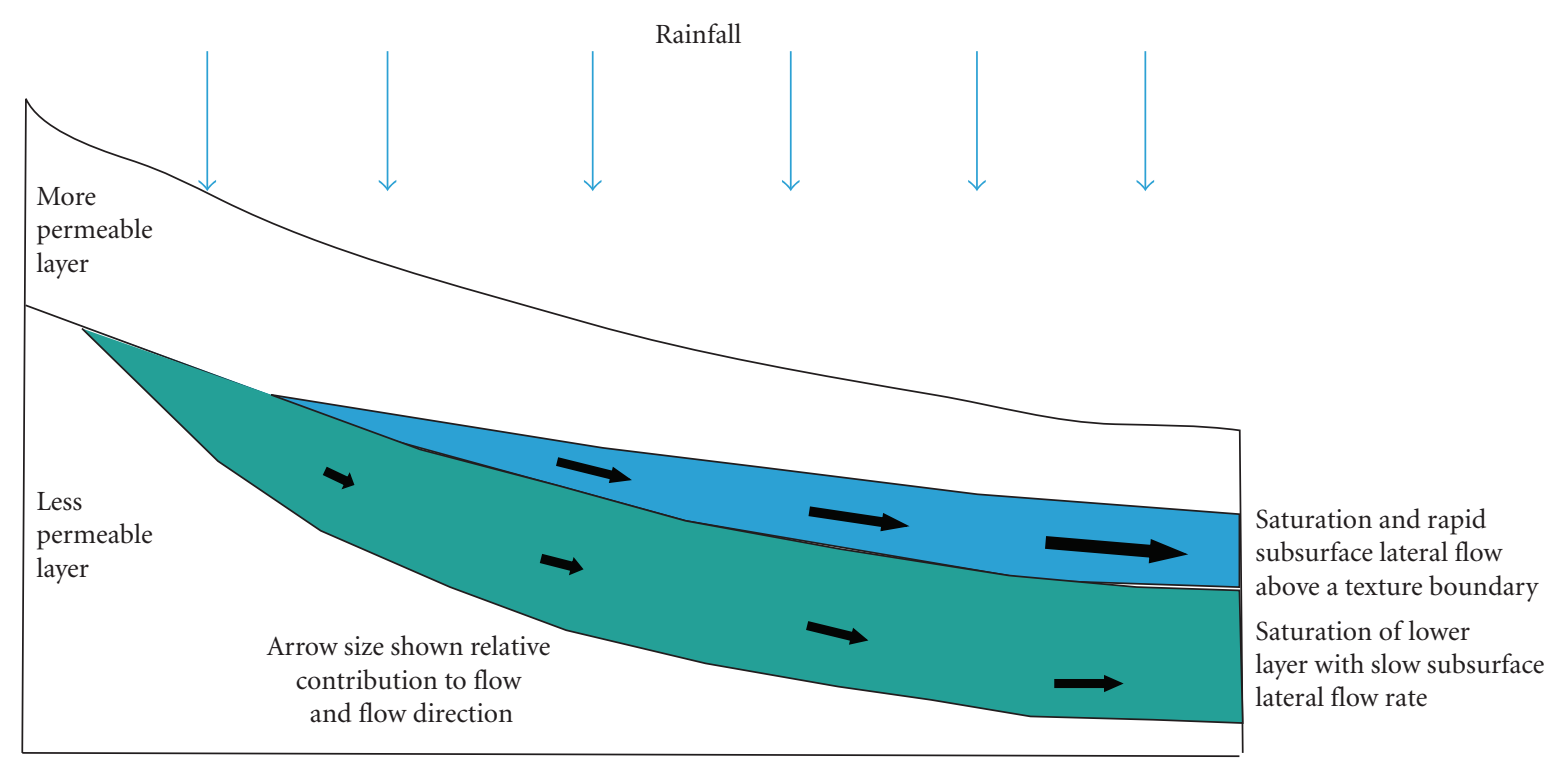

FIGURE 3: Conceptual model of subsurface flow in a texture-contrast soil (adapted from Whipkey and Kirkby [69]). Saturated layers and subsurface flow above and below the contact with an impeding layer, under conditions of steady rainfall.

is exceeded by the rainfall rate and depth of ponding [83]. Multiple pore domain models have successfully been used to predict rapid vertical movement of pesticides to groundwater via complex physical and chemical nonequilibrium processes [82]; however, their use in hillslope studies of subsurface lateral flows is limited. Use of multiple-pore domain models is limited by the large number of difficult-to-obtain soil parameters [83], and difficulties up-scaling soil hydraulic parameters from column leaching experiments or field measurements to larger scales [89].

Christiansen et al. [88] demonstrated that multiple porosity modelling could be applied at the hillslope scale to simulate the effects of macropore flow on stream discharge and groundwater levels in a small catchment $\left(1.5 \mathrm{~km}^{2}\right)$ in Zealand, Denmark [84]. By coupling the 1D vadose zone-3D groundwater hydrology model MIKE SHE [90], the ecosystem model DAISY, and 1D multiple pore domain concepts described in MACRO [91], they demonstrated that inclusion of macropores in the simulation routine increased the stream discharge and groundwater levels by less than one percent, yet increased pesticide leaching to ground water by $2-8$ times that of simulations without the macropore routine.

Tromp-van Meerveld [57] suggest that one of the reasons that hillslope hydrology has struggled to move forward from the literature published in the 1970s and 1980s is the assumption in many experimental studies and hillslope models that bedrock is impermeable to flow and hence represents a no-flow boundary condition at the soil-bedrock interface. While studies such as Tromp-Van Meerveld and McDonnell [47] and Woods and Rowe [92] have demonstrated that bedrock topography influences timing and location of subsurface flow, few modelling studies have incorporated the effect of spatially variable bedrock permeability within the model structure. Tromp-van Meerveld [57] and Graham and McDonnell [93] demonstrated the importance of allowing for heterogeneity in the bedrock topography and permeability. By including fill and spill mechanisms and preferential flow networks from the soil surface to the bedrock within the model structure, Graham and McDonnell [93] were able to reliably reproduce measured hydrograph and tracer data. Tromp-Van Meerveld and Weiler [57] also found that inclusion of bedrock leakage was required to model the subsurface flow response to multiple storms. Without bedrock leakage, recessions were too slow and the hilllslope remained too wet between storm events. Inclusion of macropore flow was also required to accurately predict the maximum depth of saturation above the soilbedrock interface and bedrock leakage. They conclude that greater model complexity was needed to simulate outflow response and the internal hillslope dynamics than is typically present in many hillslope models.

In order to improve the modelling of subsurface lateral flows in texture-contrast soils, review of the literature from catchments with shallow bedrock indicates models need to account for preferential flow between the soil surface and the soil bedrock boundary, spatial variation in the topography of the impeding layer, spill and fill mechanisms in the impeding layer, spatial variations in the permeability of the impeding layer, and preferential flow along the upper surface of the impeding layer [57]. Additionally in texture-contrast soils, Silberstein et al. [66] and Hardie [67] demonstrated that effects of antecedent soil moisture on subsoil hydraulic conductivity may need to be included in model structure.

\section{Conclusion and Research Opportunities}

Review of the literature on steep, forested catchments with shallow bedrock indicates that subsurface lateral flow results from a combination of preferential flow from the soil surface to the soil-bedrock surface, variation in the surface topography of the bedrock leading to fill and spill mechanisms 
which become more connected as antecedent soil moisture increases, and saturated channaelised flow along depressions in the bedrock surface and/or lateral flow through pore networks along the bedrock surface. In contrast, the mechanisms responsible for the development of perched watertables and subsurface lateral flow in texture-contrast soils are less well understood. Development of perched water-tables and subsurface lateral flow has often been attributed to the textural or hydraulic conductivity discontinuity between the $\mathrm{A}$ and $\mathrm{B}$ soil horizons. However, limited field studies indicate the preferential flow and spatial and temporal variations in hydraulic conductivity of the upper B horizon, which may influence whether infiltration accumulates at the A/B horizon boundary or is redistributed further down the soil profile.

In order to improve the management of texture-contrast soils, limited field data and review of the literature from catchments with shallow bedrock indicates that modelling of subsurface lateral flow in texture-contrast soils requires improved process understanding. Further field studies are required to better understand the mechanisms responsible for the development of perched water-tables and subsurface lateral flow in texture-contrast soils; studies need to determine the extent to which (i) preferential flow in the A horizon is able to bypass the soil matrix and rapidly deliver infiltrating water to the impeding layer ahead of infiltration through the soil matrix, (ii) the topography of the upper surface of the $B$ horizon results in localization of saturation and channelisation of subsurface lateral flow, (iii) macropores and shrinkage cracks prevent accumulation of infiltration on the upper surface of the B horizon, (iv) the hydraulic conductivity of the upper B horizon is influenced by antecedent soil moisture, and (v) spatial and temporal variation in the hydraulic conductivity of the B horizons can be parameterized and represented in two-dimensional, multiporosity, soil-water models.

\section{Acknowledgments}

Funding was provided by the Australian Government through the Landscape Logic Commonwealth Environmental Research Facility hub. This research was conducted whilst the first and second authors were on secondment from the Department of Primary Industries, Parks, Water and Environment, Tasmania (DPIPWE).

\section{References}

[1] R. W. Fitzpatrick, S. C. Boucher, R. Naidu, and E. Fritsch, "Environmental consequences of soil sodicity," Australian Journal of Soil Research, vol. 32, no. 5, pp. 1069-1093, 1994.

[2] R. F. Isbell, W. S. McDonald, and L. J. Ashton, Concepts and Rationale of the Australian Soil Classification, ACLEP, CSIRO Land and Water, Canberra, Australia, 1997.

[3] D. J. Chittleborough, K. R. J. Smettem, C. Kirkby et al., Clay, Phosphate and Water Movement Through a Texture Contrast Soil. Land and Water Resource Research and Development Corporation, for Project UAD1, LWRRC, Canberra, Australia, 1994.
[4] D. Tennant, G. Scholz, J. Dixon, and B. Purdie, "Physical and chemical characteristics of duplex soils and their distribution in the south-west of Western Australia," Australian Journal of Experimental Agriculture, vol. 32, no. 7, pp. 827-843, 1992.

[5] C. G. Stephens, A Manual of Australian Soils, CSIRO, Melbourne, VIC, Australia, 1953.

[6] H. C. T. Stace, G. D. Hubble, R. Brewer et al., A Handbook of Australian Soils, Glenside, Australia, 1968.

[7] K. H. Northcote, A Factual Key for the Recognition of Australian Soils, Rellim Technical, Glenside, South Australia, 1979.

[8] R. F. Isbell, The Australian Soil Classification, CSIRO, Melbourne, VIC, Australia, 2002.

[9] D. J. Chittleborough, "Formation and pedology of duplex soils," Australian Journal of Experimental Agriculture, vol. 32, no. 7, pp. 815-825, 1992.

[10] Soil Survey Staff, Keys to Soil Taxonomy, USDA-Natural Resource Conservation Service, Washington, DC, USA, 2006.

[11] W. E. Cotching, J. Cooper, L. A. Sparrow, B. E. McCorkell, and W. Rowley, "Effects of agricultural management on sodosols in northern Tasmania," Australian Journal of Soil Research, vol. 39, no. 4, pp. 711-735, 2001.

[12] I. Edwards, "Farming duplex soils: a farmer's perspective," Australian Journal of Experimental Agriculture, vol. 32, no. 7, pp. 811-814, 1992.

[13] W. K. Gardner, R. G. Fawcett, G. R. Steed, J. E. Pratley, D. M. Whitfield, and H. Van Rees, "Crop production on duplex soils in south-eastern Australia," Australian Journal of Experimental Agriculture, vol. 32, no. 7, pp. 915-927, 1992.

[14] M. Hardie, W. E. Cotching, and P. R. Zund, "Rehabilitation of field tunnel erosion using techniques developed for construction with dispersive soils," Australian Journal of Soil Research, vol. 45, no. 4, pp. 280-287, 2007.

[15] H. Morrell, "Catchment issues in farming duplex soils," Australian Journal of Experimental Agriculture, vol. 32, no. 7, pp. 981-985, 1992.

[16] M. A. Simeoni, P. D. Galloway, A. J. O’Neil, and R. J. Gilkes, "A procedure for mapping the depth to the texture contrast horizon of duplex soils in south-western Australia using ground penetrating radar, GPS and kriging," Australian Journal of Soil Research, vol. 47, no. 6, pp. 613-621, 2009.

[17] G. D. Hubble, R. F. Isbell, and K. H. Northcote, "Features of Australian soils," in Soils: An Australian Viewpoint, pp. 17-47, CSIRO, Melbourne, VIC, Australia, 1983.

[18] E. L. Greacen, "Physical properties and water relations," in Red-Brown Earths of Australia, J. M. Oades, D. G. Lewis, and K. Norrish, Eds., pp. 83-96, Waite Agricultural Research Institute, University of Adelaide and CSIRO, Adelaide, Australia, 1981.

[19] D. M. Bakker, G. J. Hamilton, D. J. Houlbrooke, and C. Spann, "The effect of raised beds on soil structure, waterlogging, and productivity on duplex soils in Western Australia," Australian Journal of Soil Research, vol. 43, no. 5, pp. 575-585, 2005.

[20] J. Brouwer and R. W. Fitzpatrick, "Interpretation of morphological features in a salt-affected duplex soil toposequence with an altered soil water regime in western Victoria," Australian Journal of Soil Research, vol. 40, no. 6, pp. 903-926, 2002.

[21] J. W. Cox, E. Fritsch, and R. W. Fitzpatrick, "Interpretation of soil features produced by ancient and modern processes in degraded landscapes. VII. Water duration," Australian Journal of Soil Research, vol. 34, no. 6, pp. 803-824, 1996.

[22] J. W. Cox and D. J. McFarlane, "The causes of waterlogging in shallow soils and their drainage in southwestern Australia," Journal of Hydrology, vol. 167, no. 1-4, pp. 175-194, 1995. 
[23] H. P. Cresswell and J. A. Kirkegaard, "Subsoil amelioration by plant roots-the process and the evidence," Australian Journal of Soil Research, vol. 33, no. 2, pp. 221-239, 1995.

[24] J. Eastham, P. J. Gregory, and D. R. Williamson, "A spatial analysis of lateral and vertical fluxes of water associated with a perched watertable in a duplex soil," Australian Journal of Soil Research, vol. 38, no. 4, pp. 879-890, 2000.

[25] C. E. Pankhurst, A. Pierret, B. G. Hawke, and J. M. Kirby, "Microbiological and chemical properties of soil associated with macropores at different depths in a red-duplex soil in NSW Australia," Plant and Soil, vol. 238, no. 1, pp. 11-20, 2002.

[26] D. J. McFarlane and D. R. Williamson, "An overview of water logging and salinity in southwestern Australia as related to the "Ucarro" experimental catchment," Agricultural Water Management, vol. 53, no. 1-3, pp. 5-29, 2002.

[27] P. J. Gregory, D. Tennant, A. P. Hamblin, and J. Eastham, "Components of the water balance on duplex soils in western Australia," Australian Journal of Experimental Agriculture, vol. 32, no. 7, pp. 845-855, 1992.

[28] O. R. Lehman and L. R. Ahuja, "Interflow of water and tracer chemical on sloping field plots with exposed seepage faces," Journal of Hydrology, vol. 76, no. 3-4, pp. 307-317, 1985.

[29] J. L. Ticehurst, Hydrological analysis for the integration of tree belt plantations into Australia's agricultural systems, Ph.D. thesis, Australian National University, 2004.

[30] M. G. Anderson and T. P. Burt, "Automatic monitoring of soil moisture conditions in a hillslope spur and hollow," Journal of Hydrology, vol. 33, no. 1-2, pp. 27-36, 1977.

[31] C. J. Ritsema, K. Oostindie, and J. Stolte, "Evaluation of vertical and lateral flow through agricultural loessial hillslopes using a two-dimensional computer simulation model," Hydrological Processes, vol. 10, no. 8, pp. 1091-1105, 1996.

[32] D. R. Weyman, "Measurements of the downslope flow of water in a soil," Journal of Hydrology, vol. 20, no. 3, pp. 267-288, 1973.

[33] J. T. McCord and D. B. Stephens, "Lateral moisture flow beneath a sandy hillslope without an apparent impeding layer," Hydrological Processes, vol. 1, no. 3, pp. 225-238, 1987.

[34] C. R. Jackson and T. W. Cundy, "A model of transient, topographically driven, saturated subsurface flow," Water Resources Research, vol. 28, no. 5, pp. 1417-1427, 1992.

[35] T. C. Atkinson, "Techniques for measuring subsurface flow on hillslopes," in Hillslope Hydrology, M. J. Kirkby, Ed., pp. 73120, John Wiley \& Sons, New York, NY, USA, 1978.

[36] J. W. Cox and R. Ashley, "Water quality of gully drainage from texture-contrast soils in the Adelaide Hills in low rainfall years," Australian Journal of Soil Research, vol. 38, no. 5, pp. 959-972, 2000.

[37] J. W. Cox, D. J. Chittleborough, H. J. Brown, A. Pitman, and J. C. R. Varcoe, "Seasonal changes in hydrochemistry along a toposequence of texture-contrast soils," Australian Journal of Soil Research, vol. 40, no. 4, pp. 581-604, 2002.

[38] J. W. Cox and A. Pitman, "Chemical concentrations of overland flow and throughflow from pastures on sloping texturecontrast soils," Australian Journal of Agricultural Research, vol. 52, no. 2, pp. 211-220, 2001.

[39] D. P. Stevens, J. W. Cox, and D. J. Chittleborough, "Pathways of phosphorus, nitrogen, and carbon movement over and through texturally differentiated soils, South Australia," Australian Journal of Soil Research, vol. 37, no. 4, pp. 679-693, 1999.

[40] K. R. J. Smettem, D. J. Chittleborough, B. G. Richards, and F. W. Leaney, "The influence of macropores on runoff generation from a hillslope soil with a contrasting textural class," Journal of Hydrology, vol. 122, no. 1-4, pp. 235-251, 1991.

[41] J. Brouwer and R. W. Fitzpatrick, "Restricting layers, flow paths, and correlation between duration of soil saturation and soil morphological features along a hillslope with an altered soil water regime in western Victoria," Australian Journal of Soil Research, vol. 40, no. 6, pp. 927-946, 2002.

[42] M. Paul Mosely, "Streamflow generation in a forested watershed, New Zealand," Water Resources Research, vol. 15, no. 4, pp. 795-806, 1979.

[43] M. G. Sklash, M. K. Stewart, and A. J. Pearce, "Storm runoff generation in humid headwater catchments: 2. A case study of hillslope and low-order stream response," Water Resources Research, vol. 22, no. 8, pp. 1273-1282, 1986.

[44] J. J. McDonnell, "A rationale for old water discharge through macropores in a steep, humid catchment," Water Resources Research, vol. 26, no. 11, pp. 2821-2832, 1990.

[45] J. McDonnell, D. Brammer, C. Kendall et al., "Flow pathways on steep forested hillslopes: the tracer, tensiometer and trough approach," in Environmental Forest Science, K. Sassa, Ed., pp. 463-474, Kluwer, Boston, Mass, USA, 1998.

[46] B. L. McGlynn, J. J. McDonnel, and D. D. Brammer, "A review of the evolving perceptual model of hillslope flowpaths at the Maimai catchments, New Zealand," Journal of Hydrology, vol. 257, no. 1-4, pp. 1-26, 2002.

[47] H. J. Tromp-van Meerveld and J. J. McDonnell, "Threshold relations in subsurface stormflow: 2 . The fill and spill hypothesis," Water Resources Research, vol. 42, no. 2, 2006.

[48] J. J. McDonnell, I. F. Owens, and M. K. Stewart, "Case study of shallow flow paths in a steep zero-order basin," Water Resources Bulletin, vol. 27, no. 4, pp. 679-685, 1991.

[49] J. J. McDonnell, M. K. Stewart, and I. F. Owens, "Effect of catchment-scale subsurface mixing on stream isotopic response," Water Resources Research, vol. 27, no. 12, pp. 30653073, 1991.

[50] W. J. van Verseveld, J. J. McDonnell, and K. Lajtha, "A mechanistic assessment of nutrient flushing at the catchment scale," Journal of Hydrology, vol. 358, no. 3-4, pp. 268-287, 2008.

[51] D. D. Brammer, Hillslope hydrology in a small forested catchment, M.S. thesis, State University of New York, Environmental Science and Forestry, Maimai, New Zealand, 1996.

[52] C. B. Graham, R. A. Woods, and J. J. McDonnell, "Hillslope threshold response to rainfall: (1) a field based forensic approach," Journal of Hydrology, vol. 393, no. 1-2, pp. 65-76, 2010.

[53] R. C. Sidle, S. Noguchi, Y. Tsuboyama, and K. Laursen, "A conceptual model of preferential flow systems in forested hillslopes: evidence of self-organization," Hydrological Processes, vol. 15, no. 10, pp. 1675-1692, 2001.

[54] R. C. Sidle, Y. Tsuboyama, S. Noguchi, I. Hosoda, M. Fujieda, and T. Shimizu, "Seasonal hydrologic response at various spatial scales in a small forested catchment, Hitachi Ohta, Japan," Journal of Hydrology, vol. 168, no. 1-4, pp. 227-250, 1995.

[55] Y. Tsuboyama, R. C. Sidle, S. Noguchi, and I. Hosoda, "Flow and solute transport through the soil matrix and macropores of a hillslope segment," Water Resources Research, vol. 30, no. 4, pp. 879-890, 1994.

[56] H. J. Tromp-Van Meerveld and J. J. McDonnell, "Threshold relations in subsurface stormflow: 1. A 147-storm analysis of the Panola hillslope," Water Resources Research, vol. 42, no. 2, 2006.

[57] H. J. Tromp-van Meerveld and M. Weiler, "Hillslope dynamics modeled with increasing complexity," Journal of Hydrology, vol. 361, no. 1-2, pp. 24-40, 2008. 
[58] D. Wang, "On the base flow recession at the Panola mountain research watershed, Georgia, United States," Water Resources Research, vol. 47, no. 3, 2011.

[59] R. E. Yoder, R. S. Freeland, J. T. Ammons, and L. L. Leonard, "Mapping agricultural fields with GPR and EMI to identify offsite movement of agrochemicals," Journal of Applied Geophysics, vol. 47, no. 3-4, pp. 251-259, 2001.

[60] T. J. Gish, W. P. Dulaney, K. J. S. Kung, C. S. T. Daughtry, J. A. Doolittle, and P. T. Miller, "Evaluating use of groundpenetrating radar for identifying subsurface flow pathways," Soil Science Society of America Journal, vol. 66, no. 5, pp. 16201629, 2002.

[61] S. Noguchi, Y. Tsuboyama, R. C. Sidle, and I. Hosoda, "Subsurface runoff characteristics from a forest hillslope soil profile including macropores, Hitachi Ohta, Japan," Hydrological Processes, vol. 15, no. 11, pp. 2131-2149, 2001.

[62] J. Freer, J. J. McDonnell, K. J. Beven et al., "The role of bedrock topography on subsurface storm flow," Water Resources Research, vol. 38, no. 12, pp. 51-516, 2002.

[63] N. J. McKenzie, D. Jacquier, R. F. Isbell, and K. Brown, Australian Soil Landscapes: An Illistrated Compendium, CSIRO, 2004.

[64] W. E. Cotching, S. Lynch, and D. B. Kidd, "Dominant soil orders in Tasmania: distribution and selected properties," Australian Journal of Soil Research, vol. 47, no. 5, pp. 537-548, 2009.

[65] M. Hardie, R. Doyle, W. E. Cotching, K. Mattern, and S. Lisson, "Influence of antecedent soil moisture on hydraulic conductivity of a series of texture-contrast soils," Hydrological Processes. In press.

[66] R. P. Silberstein, T. J. Hatton, P. Ward et al., "Modelling drainage and transient water logging in an agricultural catchment," in Proceedings of the 25th Hydrology and Water Resources Symposium and 2nd International Conference on Water Resources and Environment Research, pp. 999-1004, Institute of Engineers, Brisbane, Australia, July 1999.

[67] M. Hardie, W. E. Cotching, R. Doyle, G. Holz, S. Lisson, and K. Mattern, "Effect of antecedent soil moisture on preferential flow in a texture contrast soil," Journal of Hydrology, vol. 398, pp. 191-201, 2011.

[68] H. J. Tromp-van Meerveld, N. E. Peters, and J. J. McDonnell, "Effect of bedrock permeability on subsurface stormflow and the water balance of a trenched hillslope at the Panola mountain research watershed, Georgia, USA," Hydrological Processes, vol. 21, no. 6, pp. 750-769, 2007.

[69] R. Z. Whipkey and M. J. Kirkby, "Flow within soils," in Hillslope Hydrology, M. J. Kirkby, Ed., pp. 121-144, John Wiley \& Sons, New York, NY, USA, 1978.

[70] F. J. Cook and D. W. Rassam, "An analytical model for predicting water table dynamics during drainage and evaporation," Journal of Hydrology, vol. 263, no. 1-4, pp. 105-113, 2002.

[71] W. J. Stolte, R. J. George, and D. J. McFarlane, "Modelling subsurface flow conditions in a salinized catchment in southwestern Australia, with a view to improving management practices," Hydrological Processes, vol. 13, no. 17, pp. 2689 2703, 1999.

[72] J. L. Ticehurst, B. F. W. Croke, J. M. Spate, and A. J. Jakeman, "Development of a simple cascading bucket model for hillslope hydrology," in Modsim 2003: Integrative Modeling of Biophysical, Social, and Economic Systems for Resource Management Solutions, pp. 392-397, Modelling and Simulation Society of Australia and New Zealand, Townsville, Australia, July 2003.
[73] R. E. Smith and R. H. B. Hebbert, "Mathematical simulation of interdependent surface and subsurface hydrologic processes," Water Resources Research, vol. 19, no. 4, pp. 987-1001, 1983.

[74] P. G. Sloan and I. D. Moore, "Modeling subsurface stormflow on steeply sloping forested watersheds," Water Resources Research, vol. 20, no. 12, pp. 1815-1822, 1984.

[75] R. J. Hunt, J. Doherty, and M. J. Tonkin, "Are models too simple? Arguments for increased parameterization," Ground Water, vol. 45, no. 3, pp. 254-262, 2007.

[76] H. S. Lin, W. Kogelmann, C. Walker, and M. A. Bruns, "Soil moisture patterns in a forested catchment: a hydropedological perspective," Geoderma, vol. 131, no. 3-4, pp. 345-368, 2006.

[77] M. Weiler and J. J. McDonnell, "Conceptualizing lateral preferential flow and flow networks and simulating the effects on gauged and ungauged hillslopes," Water Resources Research, vol. 43, no. 3, Article ID W03403, 2007.

[78] D. Tsutsumi, R. C. Sidle, and K. Kosugi, "Development of a simple lateral preferential flow model with steady state application in hillslope soils," Water Resources Research, vol. 41, no. 12, pp. 1-15, 2005.

[79] M. Weiler and J. McDonnell, "Virtual experiments: a new approach for improving process conceptualization in hillslope hydrology," Journal of Hydrology, vol. 285, no. 1-4, pp. 3-18, 2004.

[80] K. Beven and P. Germann, "Macropores and water flow in soils," Water Resources Research, vol. 18, no. 5, pp. 1311-1325, 1982.

[81] J. C. van Dam, J. Huygen, J. G. Wesseling et al., Theory of SWAP Version 2.0; Simulation of Water Flow, Solute Transport and Plant Growth in the Soil-Water-Atmosphere-Plant Environment, Wageningen Institute for Environment and Climate Research DLO Winand Staring Centre, Wageningen, The Netherlands, 1997.

[82] J. Simunek and M. T. van Genuchten, "Modeling nonequilibrium flow and transport processes using HYDRUS," Vadose Zone Journal, vol. 7, no. 2, pp. 782-797, 2008.

[83] J. Simunek, N. J. Jarvis, M. T. van Genuchten, and A. Gardenas, "Review and comparison of models for describing non-equilibrium and preferential flow and transport in the vadose zone," Journal of Hydrology, vol. 272, no. 1-4, pp. 14-35, 2003.

[84] J. M. Köhne, S. Köhne, and J. Simunek, "A review of model applications for structured soils: a) water flow and tracer transport," Journal of Contaminant Hydrology, vol. 104, no. 14, pp. 4-35, 2009.

[85] J. Simunek and M. T. van Genuchten, "Contaminant transport in the unsaturated zone: theory and modelling," in The Handbook of Groundwater Engineering, J. W. Delleur, Ed., chapter 22, pp. 22-38, CRC Press, Boca Raton, Fla, USA, 2007.

[86] M. T. van Genuchten, "Closed-form equation for predicting the hydraulic conductivity of unsaturated soils," Soil Science Society of America Journal, vol. 44, no. 5, pp. 892-898, 1980.

[87] W. Durner, "Hydraulic conductivity estimation for soils with heterogeneous pore structure," Water Resources Research, vol. 30, no. 2, pp. 211-223, 1994.

[88] J. S. Christiansen, M. Thorsen, T. Clausen, S. Hansen, and C. J. Refsgaard, "Modelling of macropore flow and transport processes at catchment scale," Journal of Hydrology, vol. 299, no. 1-2, pp. 136-158, 2004.

[89] A. I. Gardenas, J. Simunek, N. Jarvis, and M. T. van Genuchten, "Two-dimensional modelling of preferential water flow and pesticide transport from a tile-drained field," Journal of Hydrology, vol. 329, no. 3-4, pp. 647-660, 2006.

[90] DHI, 1993, MIKE-SHE, Technical Reference, Manual-Water movement module-release 1.0. Danish Hydraulic Institute, Denmark. 
[91] N. J. Jarvis, The MACRO Model (Version 3.1). Technical Description and Sample Simulations, vol. 19 of Reports and Dissertations, Department of Soil Science, Swedish University of Agricultural Science, Uppsala, Sweden, 1994.

[92] R. Woods and L. Rowe, "The changing spatial variability of subsurface flow across a hillside," Journal of Hydrology New Zealand, vol. 35, no. 1, pp. 51-86, 1996.

[93] C. B. Graham and J. J. McDonnell, "Hillslope threshold response to rainfall: (2) development and use of a macroscale model," Journal of Hydrology, vol. 393, no. 1-2, pp. 77-93, 2010. 

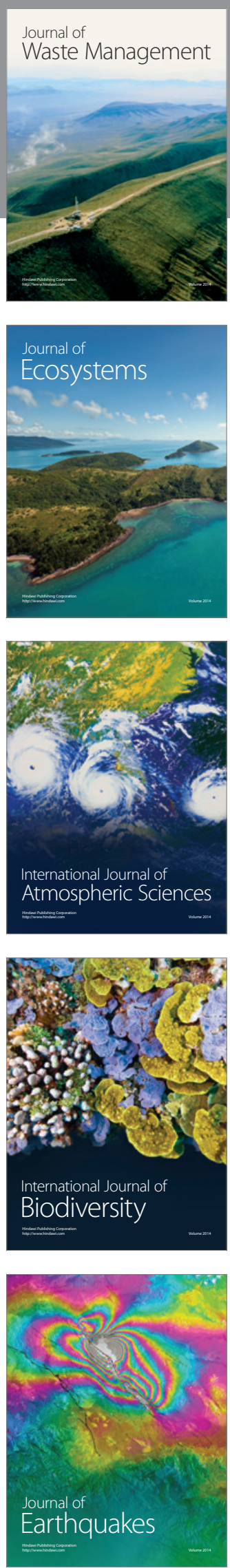
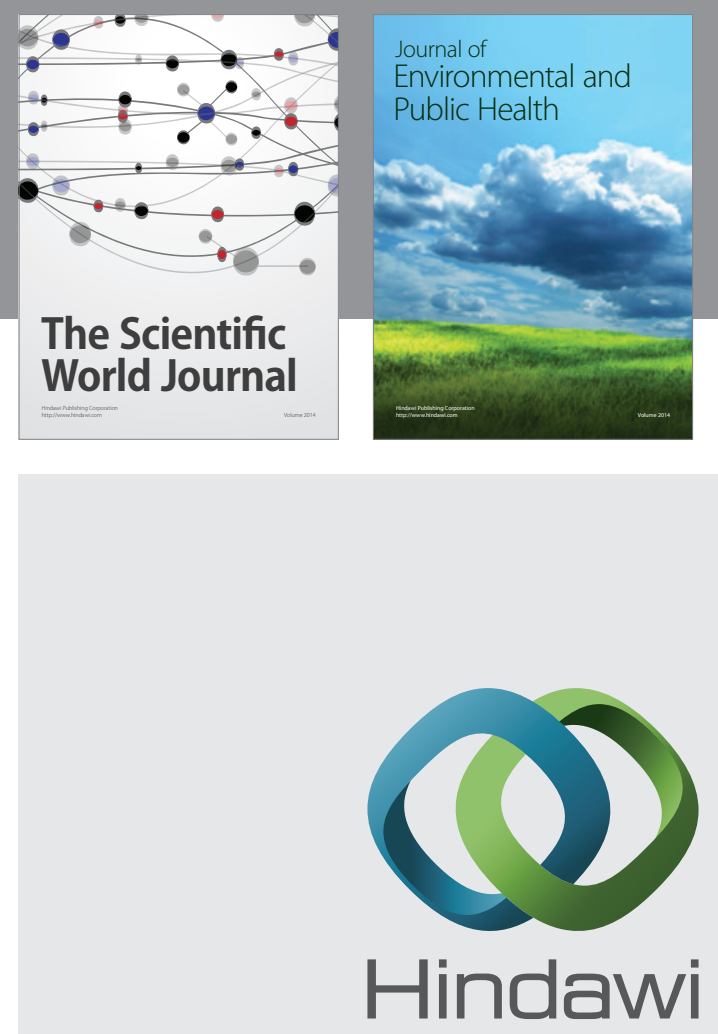

Submit your manuscripts at

http://www.hindawi.com
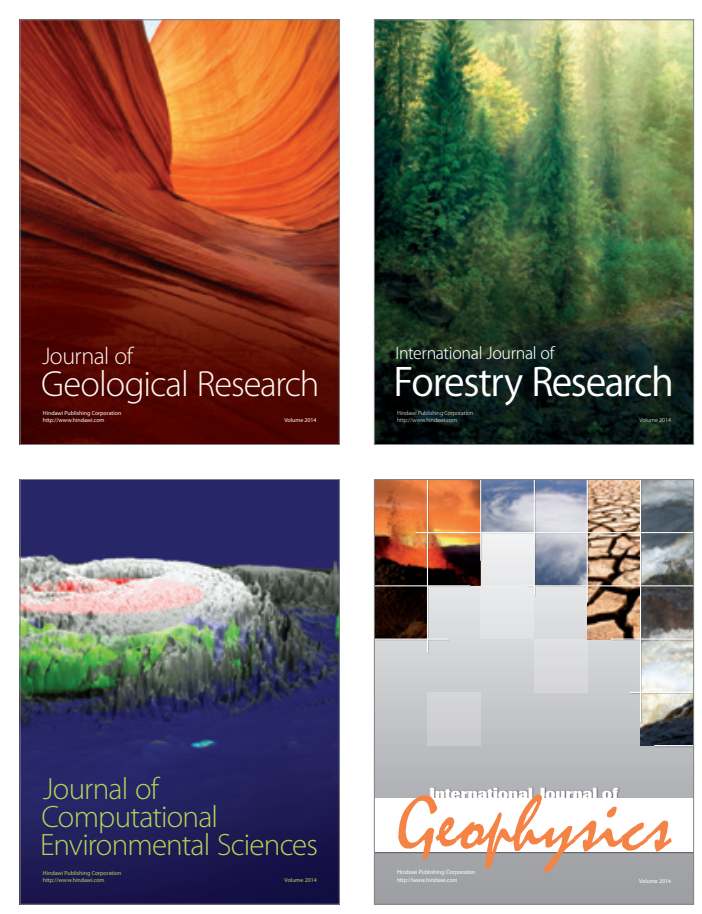
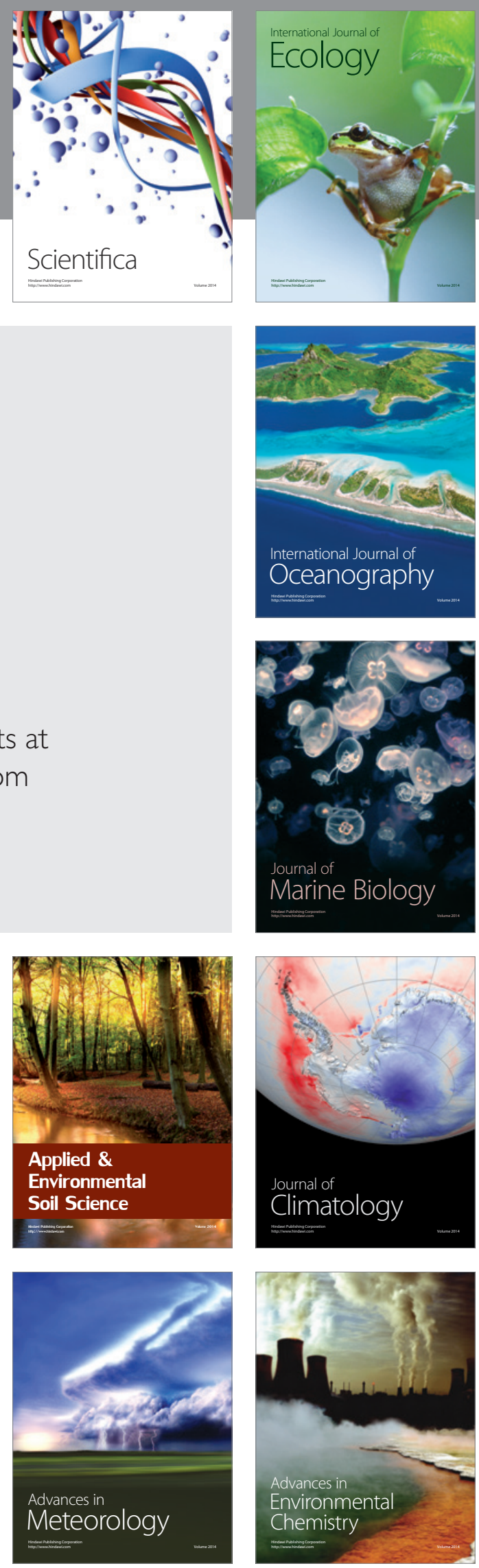